\title{
Small and Medium Enterprises in Nigeria and Adoption of International Financial Reporting Standards. An Evaluation
}

\author{
Kanu Clementina, PhD; Onuoha Nnachi, Egwu; Gabriel Isu \\ Accountancy Department, Federal University, Ndufu-Alike, Abakaliki, Ebonyi State, Nigeria. \\ Accountancy Department, Federal University, Ndufu-Alike, Abakaliki, Ebonyi State, Nigeria. \\ Federal University, Ndufu-Alike, Abakaliki, Ebonyi State, Nigeria.
}

\begin{abstract}
The study examined the readiness of Small and Medium Enterprises to adopt International Financial Reporting Standards (IFRS) considering the challenges facing SMEs in Nigeria. To obtain answers on the research questions, questionnaires and interview were used. The data collected were analyzed using descriptive statistics, and data from interview and document reviews were interpreted qualitatively. The results show that IFRS for SMEs adoption in Nigeria will be hindered by the various problems of SMEs in the Country. The findings also reveal that the challenges of SMEs in Nigeria should be attended to before the adoption of IFRS. The study concludes that despite the cumbersomeness and the anticipated problems of IFRS adoption and challenges of SMEs in Nigeria, SMEs should convert to IFRS; because adoption of FIRS will enhance better accountability, transparency, improve quality of financial reporting and add to financial reporting a global look Keywords: International financial reporting standards for SMEs, Convergence, problems of SMEs, Benefits of IFRS for SMEs in Nigeria.
\end{abstract}

\section{Introduction}

Small and Medium-sized Entities (SMEs) refer to entities that may not have public accountability and their debt or equity instruments are not traded in a public market.

Small and Medium Enterprises are seen today as the backbone of every economy throughout the world. In July 2009, International Accounting Standard Board (IASB) published IFRS for SMEs to enable SMEs have global look.

As a result of globalization, SMEs need to use IFRS in presenting their financial statement which is single reporting standard that cut across the border. The similarity in financial reporting framework and convergence of accounting standards to IFRS by SMEs in Nigeria is a vital requirement for companies to deal with the globalization efforts of capital `markets to enhance their financial communication (Gebhart, 2000), to support them to obtain financial resources from foreign capital markets (Gorrido et al, 2002) and to meet their need for a common international language of accounting (Whittington 2005). Acccording to Otchere \& Agbeibor (2012), the idea of international financial reporting standards as a single global financial reporting language has come to stay. There is no doubt that developing accounting standards can be a difficult and expensive exercise.

Although many argued that much of the disclosures and information required by full financial statements are regarded as not relevant to small and medium enterprises. Again the needs of the users of financial statements are not the same for big and small organizations.

The truth of the matter is that most economies, including the developed economies are largely driven and sustained by SMEs, not minding the fact that the companies we hear about are the big, publicly traded corporations. In the developed world, for every one big corporation, (for example, Apple Inc. or Ford Motor Corp. etc.), there are hundreds of SMEs servicing the supply and distribution chains of these companies. Ford Motors for example is serviced by SMEs that design and manufacture its thousands of auto components, its car dealerships and its maintenance workshops spread across the USA and the world. It is thus generally agreed that without SMEs, there can be no sustainable economic development. This is especially so for developing / emerging economies in Africa and Asia etc.

However, the inherent problems of poor governance, lack of transparency and accountability as a result of incomplete records and administrative bottleneck, have prevented most SMEs in Nigeria from complying with GAAP. Large proportions of SMEs started up and never make it off their business plan document, or past their first year of existence. Most of these SMEs have not reached their fullest potential in terms of growth, profitability and contribution to the economy. Based on this background, the study wishes to assess how ready SMEs in Nigeria are to adopt IFRS spite of the challenges SMEs face in Nigeria. The objective of this study is:

-To determine the readiness of SMEs to adopt IFRS despite the challenges faced by SMEs in Nigeria, according to the perception of the following:

a. users of SMEs' financial statements, 
b. accounting professionals and owners of SMEs.

c. owners of SMEs in Nigeria.

This paper has five sections. Section 1 is the introduction. Section 2 deals on the review of related literature. Section 3 is research methodology and model specification, section 4 deals with the results of the analyses, while section 5 discusses the results and concludes appropriately with some recommendations.

\section{Review Of Related Literature}

This section reviews the opinion of other researchers as related to this study.

\subsection{SMALL AND MEDIUM ENTERPRISES IN NIGERIA}

Earlier before now small and medium enterprise have been taken to be instrumental for economic growth and national development both in developed and developing countries which Nigeria is one of them through generation of employment.

Since Small and Medium Enterprises are seen today as the backbone of every economy throughout the world, (Ojeka and Dickson, 2011). SMEs are significant in the country's economy. SMEs are defined using a certain characteristics, but differs with economies. Some of these include: ownership structure, size, turnover, number of employees, total assets and capital base. These kinds of companies exist all over the continent and in all sectors in Nigeria. SMEs in Nigeria consist of the private sectors, professionals groups and associations. They drive the economy of Nigeria. Imagine where these were better funded and organized, SMEs could have contributed more to the economy.

Various studies conducted by academia, professional and governmental agencies confirm the fact that SMEs are the engine of economic growth and development. While the actual figures vary from country to country, it is believed that on average SMEs (both from the formal and informal sectors) account for between $70 \%$ and $90 \%$ of employment and $>70 \%$ of National output.

Agric. Sector accounts for $40 \%-45 \%$ of GDP in Nigeria and $70 \%$ of employment. Over $80 \%$ of the Agriculture sector is either subsistence farming or SMEs Agro-allied business

If properly setup, managed and funded, SMEs provided the much needed employment to a large section of the economy in Nigeria. SMEs provide household incomes which drives consumption and which in turn drives economic growth. Some researchers maintain that in the central and eastern Europe SMEs are perceived as the most vibrant and healthier sector of the economies in comparison with the larger entities

Also, good number of SMEs grow over the years to become huge corporations. All companies essentially start small as SMEs but some later grow and become the big corporations we love to hear and talk about example, Tantalizers, ABC Transport, Computer Warehouse Group, Ibeto Group of Companies.

Unfortunately, a large proportions of SME startup but never make it off their business plan document, or past their first year of existence.

As earlier stated, most of SMEs in Nigeria do not achieve their fullest potentials of growth and profitability. They are unable to attract any funds to start-off the business. Most SMEs (with the exception of trading companies, government contractors and oil traders) are effectively locked out of traditional sources of financing. SMEs in Nigeria are faced with numerous challenges as:

- Inadequate, inefficient, and at times, non-functional infrastructural facilities,

- inefficient administration

- absence of long-term finance to fund,

- lack of accountability and transparency/ Poor governance

-incomplete records,

-under project finance for SMEs,

-lack of scientific and technological knowledge,

-Lack of suitable training and leadership development and others.

- Poorly thought-out business ideas / concept

-Lack of separation of "owners pocket from business pocket"

- Adverse changes in total market demand

- Intensification of competition and poor response plan

- Highly demotivated staff (No defined career paths)

These have hindered them from playing the expected role in Nigeria's economic growth and development. Numerous efforts have been made by government to enhance the survival and the impact of SMEs in Nigerian economic development, but it seems that both environmental and political factors have not give way for the objective to be achieved. Hence, Molokwu B. (2005) said that unfortunately, these SMEs over the years, have been bedeviled by several inhibitions, which tend to make their growth perpetually stunted by infrastructural decay, insecurity of lives and property, multiplicity of taxation, lack of access to good and 
modern technology, lack of research and development as well as good entrepreneurship, difficulties in building coalitions and business linkages among others.

Government is not relenting in their efforts to make SMEs in Nigeria what they should be because of the prospects of SMEs in the country which some authors listed as the crucial role of engine of growth, development and industrialization, employment/ wealth creation and poverty reduction.

Molokwu maintain that SMEs are the largest employer of labor, providing livelihood for over 80 percent of the African work force especially women and the youth and that it is a well-known fact that the African economy is government-driven while SMEs are the veritable engine of growth in developed economies. Statistics have it that only about $10 \%$ of SMEs in Nigeria are involved in manufacturing while the rest are in agriculture, services and commerce. So for the sustainability of these roles, SMEs in Nigeria should be encouraged to grow to the greater height of the adoption of IFRS for SMEs will long go long way to enhance.

Many SMEs in Nigeria have being enjoining international relationships due to their better and improved performances. The issue of commercialization and privatization of government-owned companies is another avenue that helped SMEs in Nigeria to portray their efforts towards the nations development. Some SMEs are still looking for any opportunity to experience external business actions. Due to the place of SMEs in the nation's economy and the benefits that would accrue to SMEs in Nigeria, SMEs need to use IFRS in presenting their account which is single reporting standard that cut across the border. The reason is because IFRSs have been globally accepted as a key for reliable, understandable and transparent financial reporting. So the issue of IFRS is a welcomed idea that helps SMEs for international interaction.

\subsection{IFRS FOR SMEs IN NIGERIA}

IASB, 2009 said that IFRS is designed for SMEs and it is a self-contained standard of 230 pages, designed to meet the needs and capabilities of Small and Medium sized Entities (SMEs), which are estimated to account for over 95 per cent of all the companies around the world.

Nobes (2004) said that due to the problems associated with worldwide accounting diversity, attempts to reduce accounting differences across countries have been ongoing debates for decades and as a result of the advantages it provides for countries and multinational companies, many countries adopt International Financial Reporting Standards. Although many argued that much of the disclosures and information required by full financial statements is regarded as not relevant to small and medium enterprises.

Again the needs of the users of financial statement are not the same for big and small organizations, especially in Nigeria where SMEs is merely family business and some do not have accounting records.

The costs of SMEs reporting financial statements in IFRS should be high, the resulting statements would not meet the objective of decision-usefulness. Many SMEs in Nigeria keep incomplete records in their book keeping. Some do not have nor see reasons for keeping accounting records yet they contribute immensely to the development of the economy.

SMEs do not have "public accountability" hence they do not need to disclose as much information as the listed companies do. Again, the application of IFRSs by SMEs would not be beneficial for them from the view of the cost involved. SMEs generally have limited staff and resource and they will face significant costs while adopting IFRSs. Goh/Holt (2006) define this as "a unique financial burden" that is placed on SMEs because they must pay a proportionally higher cost than big companies for the same benefit. The users of SME financial statements would be creditors, suppliers, employees and the tax authorities may focus on different information compared with the users of financial statements of listed companies. They may be more interested in short term cash flows, liquidity and interest coverage (Sivaram, 2006).

However, Cheney (2004) mention the goal of IFRS for SMEs project of the IASB as: to reduce the burden of disclosure for smaller companies, while preserving the recognition and measurement principles of international standards.

Iyoha and Faboyede, 2011; Apostolos et al., 2010; Jermakowicz et al. 2007; Alicja et al., 2007; Susana et al., 2007; Jermakowicz, 2004) also maintain that adoption of IFRS has a number of important benefits for a wide range of stakeholders such as, increased comparability of consolidated accounts, increased levels of transparency, better access to the global capital markets and other stakeholders would benefit from overall better reporting and information.

The secondary research made in less developed countries such as South Africa, Turkey, Kenya, Ghana (Bohušova, 20 11) found out that the adoption of the IFRS for SMEs would improve their access to financial funds, would help them to penetrate foreign markets and thus their financial situation and performance would be improved. Therefore, Nigeria would not be exceptional to this case.

Arsoy, A. P., Sipahi, B.,( 2008) made it clear that the adoption of IFRS for SMEs in Turkey changed the accounting system and met the needs of the users of SME financial statements, although the adoption process was complex, because of the corporate structure of SMEs and the limited education opportunities about IFRS. Pricewaterhousecoopers 2006, IASB 2007) opine that the benefit of the IFRS for SMEs are as follows; 
- Adoption of IFRS for SMEs will improve the comparability of financial information of SMEs at either national or international levels.

- Adoption of IFRS for SMEs will make easier to implement planned cross-border acquisitions and to initiate proposed partnerships or cooperation agreements with foreign entities.

- Adopting IFRS for SMEs can help SMEs to reach international markets.

- Adoption of IFRS for SMEs will have a positive effect on the credit rating scores of enterprises, this will strength SMEs' relationships with credit institutions.

- Vendors want to evaluate the financial health of buyers before they sell goods or services on credit. The adoption of IFRSs will enhance the financial health of the SMEs.

The transition date for SMEs in Nigeria is January 2013 and should report fully on December 2014.

\section{Research Methodology}

The survey research is used, which involved the use of questionnaire. The questionnaire is based on receiving perceptions of respondents (professionals, users of financial statements and managers/owners of SMEs) on the readiness of SMEs in Nigeria to adopt IFRS considering the problems of SMEs in Nigeria.

This study thus seeks to answer the following research question:

Whether SMEs in Nigeria are ready to adopt IFRS with the problems of SMEs in Nigeria based on the perception of:

-accounting professionals

-users of financial statements

-managers/owners of SMEs

The process of data collection included pre-tested and administration of questionnaire, after which the data was captured and analyzed. We administered 500 questionnaires to the users of financial statements and accounting practitioners and owners of SMEs in the south East zone of Nigeria only $350(70 \%)$ were returned 100,150 and 100 from accounting professionals, users' of financial statements and owners of SMEs respectively.

Our reason to choose accountants for this research is that they are professionals who are going to report on the financial performance of SMEs in accordance with the requirement of IFRS, the users will use the financial statements for decision making and the managers/ owners will make available the information to be used in preparing the financial statements.

The responses presented below as:

$\begin{array}{lcc}\text { VERY READY } & \text { VR } \\ \text { READY } & \mathrm{R} \\ \text { LESS READY } & \text { LR } & \\ \text { NOT READY } & \mathrm{NR} & \\ \text { NO RESPONSE } & \text { NRP } & \text { UFS } \\ \text { USERS OF FINANCIAL STATEMENTS } & \text { CA } \\ \text { CHARTERED ACCOUNTANTS } & \text { OS }\end{array}$

IV. Data Presentation And Analyses

The data were analyzed using descriptive statistics including percentages and vertical cone.

Table 4.1: RESPONSES COLLECTED

\begin{tabular}{|c|c|c|c|c|}
\hline & $\begin{array}{l}\text { Users of SMEs Financial } \\
\text { St. }\end{array}$ & Accountants/ Professionals & $\begin{array}{l}\text { Manager/Ow } \\
\text { ners of SMEs }\end{array}$ & Total \\
\hline & N0.of response & N0.of response & $\begin{array}{ll}\text { No. } & \text { of } \\
\text { response } & \\
\end{array}$ & No. of response \\
\hline Very ready & 38 & 40 & 35 & 113 \\
\hline Ready & 40 & 70 & 30 & 140 \\
\hline Less ready & 7 & 25 & 20 & 52 \\
\hline Not ready & 10 & 10 & 5 & 25 \\
\hline No response & 5 & 5 & 10 & 20 \\
\hline Total & 100 & 150 & 100 & 350 \\
\hline
\end{tabular}




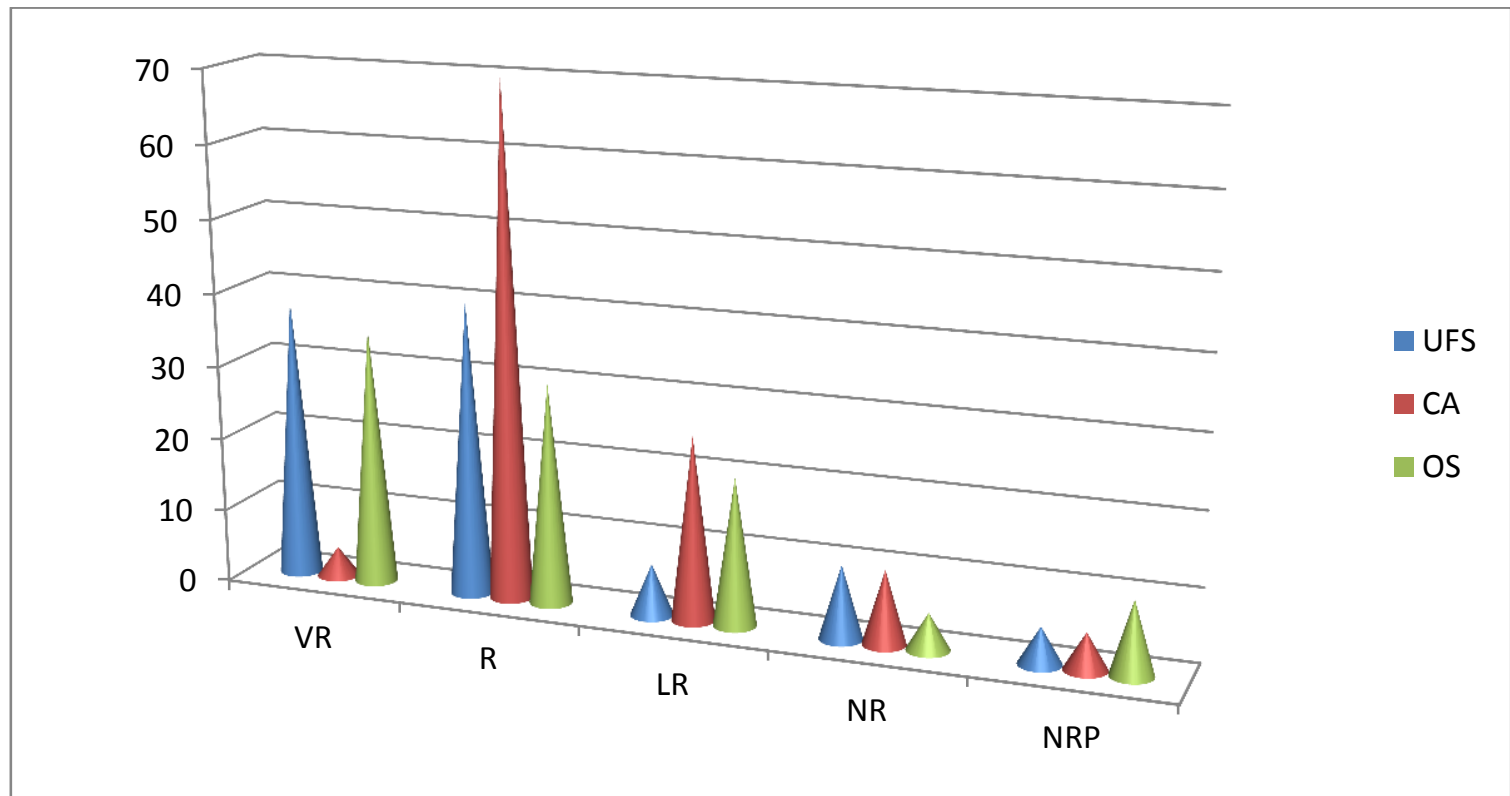

RESPONSES IN PERCENTAGE.

\begin{tabular}{|c|c|c|c|c|}
\hline & VR \$ R \% & LR $\%$ & NR $\%$ & NRP \\
\hline $\mathbf{C A}$ & 23.01 & 2 & 2.85 & 1.23 \\
\hline UFS & 31.42 & 7.14 & 2.85 & 1.23 \\
\hline OS & 18.57 & 5.86 & 1.3 & 2.54 \\
\hline TOTAL & $73 \%$ & $15 \%$ & $7 \%$ & $5 \%$ \\
\hline
\end{tabular}

\section{Discussion of the findings}

The data collected from Chartered Accountants, Users of financial Statements and managers and owners of Small and medium Enterprises as represented in percentage show that the total response from very ready and ready is $73 \%$, less ready is $15 \%$, no ready is $7 \%$ and no response is $5 \%$, Data represented with cones from chartered accountants, very ready 40 , ready 70 , less ready 25 , not ready 10 , no response 5 , users of financial statements, very ready 38 and ready 40, less ready 7 , not ready 10 , no response 5, owners of small and medium enterprises and very ready 35 and ready 30, Less ready 20, not ready 5, no response 10 , The result obtain from the perception of Charted accountants, users of financial statements and owners of small and medium and enterprises show that SMEs are ready to adopt IFRS despite the challenges of SMEs in Nigeria.

Data collected from interview conducted indicate that SMEs should adopt IFRS because SMEs constitute the major economic hub of the nation due of employment generation and contributions to nation's GDP. Again, although the costs in terms of people, resources, time and processes appear high, the benefits of improved transparency, accountability and ease of comparison far out-weigh those costs. SMEs that adopt IFRS will become easier to manage and attract labor and capital.

\subsection{CONCLUSION}

Based on the results that have been already presented from our field study, we conclude that from the viewpoint of Chartered Accountants, Users of financial statements and owners of Small and medium enterprises, that adoption of IFRS by SMEs can be seen as a required effort to the growth and survival of Small and medium enterprises. Although IFRS for SMEs is costly and burdensome but the adoption of IFRS will enhance competitive advantage, potentials for growth and sustainability of SMEs in Nigeria. Adoption of IFRS by SMEs in Nigeria will encourage comparison of financial statements within the industry, across industries, improved transparency and accountability globally.

\subsection{RECOMMENDATION}

Based on the findings of this study, the following recommendations were made:

-The adoption of IFRS for SMEs in Nigeria should be gradual but sustained process.

- Adoption of IFRS by SMEs in Nigeria should beginning with enlightenment campaigns.

- Training on IFRS is required for SMEs to have required skill and competence as required for IFRS accounting.

-Government should support the adoption of IFRS by solving the problems of SMEs. 
- Adoption of IFRS by SMEs should enhance fair value reporting instead of historical reporting.

\section{References}

[1]. AlicjaJaruga, Justyna Fijalkowska, Malgorzata J. Baranowska \& Maciej Frendzel (2007): The Impact of IAS/IFRS on Polish Accounting Regulations and their Practical Implementation in Poland, Accounting in Europe.

[2]. Apostolos A. Ballas, Despina Skoutela and Christos A. Tzovas (2010), The relevance of IFRS to an emerging market: evidence from Greece. Managerial Finance Vol. 36 No. 11

[3]. Arsoy, A. P., Sipahi, B., 2008: International fi nancial reporting standards for small and medium sized entities and the Turkish case, Ankara Universitesi SBF Dergisi

[4]. Cheney. G. (2004), "IASB and IFAC Recognize Needs of Smaller Companies," Accounting Today.

[5]. Cleminson, J \& E Rabin 2002. The Reporting Problems Faced by Small Businesses in South Africa. Paper presented at the Southern African Accounting Association biennial conference, Port Elizabeth.

[6]. Garrido, Pascual/ Leon, Angel/ Zorio, Ana (2002), "Measurement of Formal Harmonization Progress: the IASC Experience," The International Journal of Accounting

[7]. Gebhart, Günther (2000), "The Evolution of Global Standards in Accounting," Brookings-Wharton.

[8]. Goh, Steven/ Holt, Graham(2006), "Accounting Standards for SMEs: Reporting Requirements".

[9]. IASB, (2004) Preliminary Views on Accounting Standards for Small and Medium sized

[10]. IASB (2007) Exposure draft on the proposed IFRS for small and medium sized Entities. London: IASB

[11]. IASB, (2009) International Financial Reporting Standards (IFRS) for Small and Medium size Enterprises (SMEs). London: IASB

[12]. IFRS: About the IFRS Foundation and the IASB. Ifrs.org. Web. 11 Dec. 2011

[13]. http://www.ifrs.org/the+organization/IASCF+and+IASB.html.

[14]. Iyoha, F.O. and Faboyede, S.O. (2011), Adopting international financial reporting standards. (IFRS) - a focus on Nigeria, International journal of research in commerce \& management volume no: 2 , issue no. 1 .

[15]. Jermakowicz Eva K. (2004): Effects of Adoption of International Financial Reporting Standards in Belgium: The Evidence from BEL-20 Companies, Accounting in Europe.

[16]. Jermakowicz, E.K., Prather-Kinsey, J. and Wulf, I. (2007), the value relevance of accounting income reported by DAX-30 German companies, Journal of International Financial Management and Accounting, Vol. 18 No. 3.

[17]. Molokwu B.(2005), Challenges of Small and Medium Enterprises in Nigeria. Conference paper

[18]. Nobes C., Parker R. (2004). Comparative International Accounting, Prentice Hall, 2004.

[19]. Ojeka, Stephen A. and Dr. O. Mukoro Dickson (2011) International Financial Reporting Standard and SMEs in Nigeria: Perceptions of Academic International Journal of Research in Commerce \& Management vol. 2.

[20]. Otchere \& Agbeibor, (2012) The International Financial Reporting Standard for Small and Medium-sized Entities (IFRS for SMES): Suitability for small businesses in Ghana

[21]. PricewaterhouseCoopers, (2003), Illuminating Values: The Business Impact of IFRS [online]. Available: http://www.pwcglobal.com

[22]. Pricewaterhousecoopers, (2006), "IFRS for SMEs: Is it Relevant for your Business?"

[23]. Sivaram, N. (2006), "The Future of Financial Reporting- SME Standards," Business Times, 21March 2006.

[24]. Whittington, G. (2005), "The Adoption of International Accounting Standards in the

[25]. European Union," European Accounting Review, 14. 